\title{
STRATEGI PENGEMBANGAN AGROINDUSTRI VCO DI KABUPATEN KULON PROGO
}

\section{(VCO AGROINDUSTRIAL DEVELOPMENT STRATEGY IN KULON PROGO REGENCY)}

\author{
Retno Lantarsih \\ Program Studi Agribisnis, Fakultas Pertanian, \\ Universitas Janabadra, Yogyakarta
}

\begin{abstract}
VCO (Virgin Coconut Oil) is a diversified agroindustry products made from coconut. This study aims to design the VCO small agroindustrial development strategy. This study used SWOT (Strength, Weakness, Opportunity, Threat) analysis. The results showed that VCO Agroindustries in the small industries category are in a position of turn around. This position was to overcome weaknesses and to exploit the opportunities available.
\end{abstract}

Keyword: Virgin Coconut Oil, Agroindustry, SWOT Analysis

\section{PENDAHULUAN}

Secara umum sektor agroindustri di Indonesia memiliki peluang dan kelebihan untuk dapat dikembangkan. Keberadaan agroindustri di Indonesia didukung oleh ketersediaan bahan baku yang melimpah, sebagian penduduk Indonesia tergantung dari sektor pertanian, kandungan bahan baku impor yang relatif rendah, dan adanya peluang perluasan pasar domestik maupun ekspor (Masyhuri, 2000). Namun demikian, sektor agroindustri juga mempunyai tantangan dan kelemahan. Tantangan yang paling besar adalah perdagangan bebas, karena semua negara akan berusaha untuk memperebutkan pasar dunia. Masing-masing negara akan berusaha untuk selalu meningkatkan kuantitas, kualitas dan efisiensi produksinya agar mempunyai keunggulan komparatif dan kompetitif (Soetrisno,1993).

Minyak kelapa murni $(\mathrm{VCO}=$ Virgin Coconut Oil)) merupakan salah satu produk diversifikasi agroindustri berbahan baku kelapa. VCO adalah minyak yang diproses langsung dari daging buah kelapa segar atau santan segar tanpa pemurnian, pemutihan atau penghilangan bau. Menurut Rindengan dan Novarianto (2004), minyak kelapa murni sangat bermanfaat bagi kesehatan tubuh manusia. Manfaat VCO diantaranya adalah mengurangi resiko kanker, membantu mencegah infeksi virus, mendukung sistem kekebalan tubuh, mencegah osteoporosis, membantu mengontrol diabetes, memulihkan kembali kehilangan berat badan, menyediakan sumber energi dengan cepat, 
menyediakan nutrisi, membantu kulit tetap lembut dan halus, tidak menaikkan kolesterol darah, dan tidak menyebabkan kegemukan.

Di Kabupaten Kulon Progo terdapat cukup banyak produsen VCO. Agroindustri $V C O$ merupakan peluang usaha yang mampu memberikan nilai tambah produk pertanian yang berperan memberikan sumbangan terhadap pendapatan keluarga, dan membuka kesempatan kerja pada masyarakat setempat. Terjadinya perubahan lingkungan stategis seperti globalisasi ekonomi, otonomi daerah, perubahan preferensi konsumen, perhatian terhadap pelestarian lingkungan memerlukan perubahan dan penyesuaian perencanaan strategi usaha agar tetap memiliki daya saing yang tinggi. Tulisan ini bertujuan untuk menemukan strategi pengembangan agroindustri $V C O$ di Kabupaten Kulon Progo yang termasuk dalam kategori industri kecil dengan mensintesis kekuatan, kelemahan, peluang, dan ancaman.

\section{METODOLOGI}

Metode dasar yang dipergunakan dalam penelitian ini adalah metode penelitian deskriptif. Penelitian ini menggunakan data yang diambil terlebih dahulu untuk menjelaskan fenomena yang terjadi dan menganalisanya, sehingga keakuratan dan kesempurnaannya telah teruji (Babbie, 1983). Penelitian ini dilaksanakan pada tahun 2008 di Kabupaten Kulon Progo Propinsi Daerah Istimewa Yogyakarta pada agroindustri VCO yang termasuk dalam kategori industri kecil. Data yang dikumpulkan berupa data primer maupun data sekunder. Untuk melakukan sintesis terhadap kekuatan, kelemahan, peluang, dan ancaman yang terdapat dalam agroindustri VCO digunakan analisis SWOT (Strength, Weakness, Opportunity, Threat).

\section{HASIL DAN PEMBAHASAAN}

\section{Hasil Analisis SWOT Agroindustri VCO di Kabupaten Kulon Progo}

Pengembangan agroindustri VCO di Kabupaten Kulon Progo dipengaruhi oleh beberapa faktor baik internal maupun eksternal yang meliputi kekuatan, kelemahan, peluang dan ancaman.

\section{Faktor Internal.}

Faktor internal meliputi faktor kekuatan dan kelemahan yang terdapat pada Agroindustri VCO disajikan dalam Tabel 1. 
Tabel 1. Faktor Internal (Kekuatan dan Kelemahan) Pengembangan Agroindustri VCO yang Tergolong dalam Industri Kecil di Kabupaten Kulon Progo Tahun 2008

\begin{tabular}{|c|c|c|c|c|c|c|c|}
\hline \multirow{2}{*}{$\begin{array}{c}\text { No Variabel } \\
\text { Internal }\end{array}$} & \multirow[b]{2}{*}{ Bobot } & \multicolumn{3}{|c|}{ Kekuatan } & \multicolumn{3}{|c|}{ Kelemahan } \\
\hline & & Skala & & Nilai & Skala & & Nilai \\
\hline 1 Ketersediaan bahan baku & 0.1 & & 4 & 0.4 & & & \\
\hline 2 Kualitas bahan baku yang digunakan & 0.1 & & 3 & 0.3 & & & \\
\hline 3 Kontinuitas bahan baku & 0.05 & & 3 & 0.15 & & & \\
\hline 4 Motivasi dalam berusaha & 0.05 & & 4 & 0.2 & & & \\
\hline 5 Tingkat ketrampilan & 0.05 & & 4 & 0.2 & & & \\
\hline 6 Tingkat adopsi teknologi & 0.1 & & 4 & 0.4 & & & \\
\hline 7 Standar kualitas produk yang diinginkan & 0.05 & & 3 & 0.15 & & & \\
\hline 8 Ukuran dan produktivitas gugus penjualan & 0.15 & & & & & 5 & 0.7 \\
\hline 9 Kerjasama dengan jaringan distribusi & 0.1 & & & & & 4 & 0.40 \\
\hline 10 Kemampuan menembus pasar potensial & 0.1 & & & & & 4 & 0.40 \\
\hline 11 Diversifikasi produk & 0.05 & & & & & 5 & 0.25 \\
\hline 12 Kelancaran pembayaran penjualan produk & 0.1 & & & & & 4 & 0.40 \\
\hline Jumlah & 1 & & & 1.8 & & & 2.20 \\
\hline
\end{tabular}

Keterangan : Nilai faktor internal $=(+1.80)+(-2.20)=(-0.40)$

Kekuatan yang berpotensi untuk dikembangkan pada agroindustri VCO di Kabupaten Kulon Progo adalah ketersediaan, dan kontinuitas ketersediaan bahan baku, kualitas bahan baku yang digunakan, adanya motivasi dalam berusaha, tingkat ketrampilan, tingkat adopsi teknologi, standar kualitas yang diinginkan.

Sementara itu masih terdapat beberapa kelemahan dalam agroindustri VCO di Kabupaten Kulon Progo, diantaranya adalah (i) ukuran dan produktivitas gugus penjualan dinilai kurang baik, karena sebagian dari penjualan VCO sangat ditentukan oleh adanya pesanan, sementara pesanan VCO sangat tidak menentu; (ii) kerjasama dengan jaringan distribusi dinilai sangat tidak baik karena jaringan distribusi yang ada belum terbina secara kontinyu, meskipun sudah banyak dilakukan terobosan baru untuk memperkenalkan produk; (iii) kemampuan menembus pasar potensial yang kurang baik karena meski terdapat konsumen potensial, dan tetap melakukan upaya untuk memperkenalkan produk kepada konsumen baik melalui pameran, internet maupun kenalan dan kerabat serta didukung oleh mutu produk yang berkualitas namun pada kenyataannya upaya tersebut belum memberikan hasil seperti yang diharapkan; (iv) diversifikasi produk berbahan baku kelapa dinilai sangat tidak baik karena produsen VCO hanya memfokuskan diri untuk memproduksi VCO dan produk sampingan dari VCO. Produsen VCO belum mengembangkan upaya diversifikasi produk berbahan baku kelapa; (v) kelancaran pembayaran penjualan produk dinilai kurang baik. 


\section{Faktor Eksternal}

Faktor eksternal yang tediri dari peluang dan ancaman yang terdapat pada agroindustri VCO disajikan dalam Tabel 2. Peluang dalam agroindustri VCO di Kabupaten Kulon Progo diantaranya adalah: (i) tersedianya sarana dan prasarana transportasi, (ii) dukungan Pemda Kabupaten Kulon Progo untuk mempromosikan produk VCO, (iii) kinerja penyuluh, (iv) tersedianya akses kredit, (v) terjalinnya pola kemitraan terutama kemitraan dengan industri rumah tangga, (vi) konsumen potensial luar negeri, dan (vi) konsumen potensial dalam negeri. Ancaman dalam agroindustri di Kabupaten Kulon Progo meliputi : (i) munculnya teknologi baru yang biasanya diadopsi oleh industri menengah, sehingga akan mengancam eksistensi industri kecil, (ii) adanya inflasi menyebabkan semakin tingginya biaya produksi, (iii) ketatnya persaingan karena jumlah produsen di wilayah lokal sudah cukup banyak, sementara pertumbuhan pasar potensial berjalan lambat, (iv) pesanan yang tidak menentu, (v) munculnya persaingan penggunaan bahan baku (kelapa) untuk produk non VCO. Hal ini dipicu oleh kenaikan harga minyak goreng di pasar, sehingga banyak orang kembali menggunakan minyak kelapa.

Tabel 2. Faktor Eksternal (Kekuatan dan Kelemahan) Pengembangan Agroindustri VCO di Kabupaten Kulon Progo Tahun 2008

\begin{tabular}{|c|c|c|c|c|c|c|c|}
\hline \multirow{2}{*}{$\begin{array}{ll}\text { No } & \text { Variabel } \\
& \text { Eksternal } \\
\end{array}$} & \multirow[b]{2}{*}{ Bobot } & \multicolumn{3}{|c|}{ Peluang } & \multicolumn{3}{|c|}{ Ancaman } \\
\hline & & Skala & & Nilai & Skala & & Nilai \\
\hline 1 Transportasi & 0.1 & & 5 & 0.5 & & & \\
\hline 2 Dukungan Pemda dalam promosi produk & 0.1 & & 4 & 0.4 & & & \\
\hline 3 Kinerja penyuluh & 0.05 & & 4 & 0.2 & & & \\
\hline 4 Munculnya teknologi baru & 0.05 & & & & & 4 & 0.20 \\
\hline 5 Inflasi & 0.05 & & & & & 4 & 0.20 \\
\hline 6 Akses kredit & 0.05 & & 3 & 0.15 & & & \\
\hline 7 Pola kemitraan & 0.1 & & 4 & 0.4 & & & \\
\hline 8 Ketatnya persaingan & 0.1 & & & & & 5 & 0.50 \\
\hline 9 Pesanan yang tidak menentu & 0.1 & & & & & 5 & 0.50 \\
\hline 10 Persaingan penggunaan bahan baku & 0.1 & & & & & 4 & 0.40 \\
\hline 11 Konsumen potensial luar negeri & 0.1 & & 3 & 0.3 & & & \\
\hline 12 Konsumen potensial dalam negeri & 0.1 & & 4 & 0.4 & & & \\
\hline Jumlah & 1 & & & 2.35 & & & 1.80 \\
\hline
\end{tabular}

Keterangan : Nilai faktor eksternal $=(+2.35)+(-1.8)=+0.55$

\section{Pembahasan}

Beberapa aspek yang perlu diperhatikan dalam pengembangan agroindustri VCO di Kabupaten Kulon Progo yang termasuk dalam kategori industri kecil adalah ketersediaan, kualitas, dan kontinyuitas bahan baku. Buah kelapa sebagai sumberdaya lokal yang menjadi faktor utama dalam produksi 
VCO. Faktor lain yang perlu dipertimbangkan adalah motivasi dalam berusaha dan tingkat ketrampilan pelaku agroindustri, serta tingkat adopsi teknologi dan standar kualitas yang diinginkan.

Kabupaten Kulon Progo sebagai daerah pesisir yang memiliki banyak pohon kelapa. Oleh karena itu ketersediaan buah kelapa sebagai bahan baku utama dalam agroindustri VCO cukup tersedia. Selain itu, kualitas buah kelapa yang digunakan dalam agroindustri cukup baik. Hal ini akan mempengaruhi kualitas VCO yang dihasilkan. Buah kepala yang baik untuk dijadikan bahan baku dalam pembuatan VCO adalah buah kelapa yang tebal, kering, segar, sehat. Bahan baku yang diperlukan dalam agroindustri VCO tersedia secara kontinyu. Kontinyuitas bahan baku sangat diperlukan agar agroindustri VCO dapat berjalan sepanjang tahun. Pengusaha agroindustri VCO tidak membeli buah kelapa segar dalam jumlah besar karena selain dibutuhkan modal yang lebih besar, penyimpanan buah kelapa yang terlalu lama akan menurunkan kualitas bahan baku. Bahan baku agroindustri VCO (buah kelapa segar) berasal dari produksi kelapa di wilayah setempat. Hal ini akan mempermudah produsen VCO untuk memperoleh bahan baku, tentunya dengan harga yang lebih murah bila dibandingkan dengan bahan baku yang berasal dari wilayah lain. Ketersediaan kelapa di Kabupaten Kulon Progo cukup memadai, meskipun pada saat tertentu produsen VCO menggunakan bahan baku dari luar wilayah yaitu dari Kabupaten Purworejo.

Untuk menumbuhkan agroindustri sangat dibutuh sumber daya manusia (SDM) yang memiliki motivasi yang tinggi untuk berusaha. Keuletan SDM akan mendorong pelaku usaha tanggap terhadap setiap peluang yang ada dan dengan tangguh mengatasi segala hambatan yang dihadapi. Faktor internal lain yang menjadi kekuatan dalam agroindustri VCO adalah tingkat ketrampilan SDM. Tenaga kerja yang terampil sangat diperlukan dalam agroindustri VCO. Pada umumnya ketrampilan tenaga kerja diperoleh melalui pelatihan yang diprakarsai oleh Pemerintah Daerah Kulon Progo. Tenaga kerja yang digunakan dalam agroindustri VCO di Kulon Progo berasal dari wilayah setempat. Pengusaha agroindustri VCO (dalam kategori industri kecil) di Kabupaten Kulon Progo selalu berupaya untuk meningkatkan standar kualitas produk yang diinginkan. Hal ini dilakukan untuk meningkatkan kualitas VCO yang dihasilkan, sehingga akan mendapat kepercayaan dari konsumen. Upaya yang dilakukan untuk menjaga kualitas VCO yang dihasilkan adalah dengan penggunaan bahan baku yang berkualitas maupun pengujian laboratorium yang bekerja sama dengan Universitas Gadjah Mada.

Tersedianya sarana tranportasi yang baik sangat mendukung kelancaran distribusi bahan baku maupun produk VCO yang dihasilkan. Hal ini dapat menekan biaya produksi. Produk VCO dijual di wilayah Kabupaten Kulon Progo dan sekitarnya baik untuk memenuhi pesanan maupun melalui kerjasama dengan jaringan distribusi (apotik, dan koperasi). Pada saat tertentu, produsen VCO memasarkan produk VCO ke luar wilayah Yogyakarta bahkan sampai ke pasar luar negeri. Untuk pemasaran di luar wilayah DIY cukup potensial, tetapi belum dimanfaatkan secara optimal. Dukungan Pemda Kabupaten Kulon Progo 
untuk mempromosikan produk VCO mempunyai andil yang sangat besar terhadap keberhasilan pelaku agroindustri untuk mempromosikan produk kepada konsumen dalam maupun luar negeri sehingga produk VCO memperoleh pasar yang lebih luas. Sebagai contoh, dalam setiap kegiatan pengenalan produk unggulan wilayah, maka VCO menjadi salah satu produk yang dipromosikan. Beberapa hal yang sangat diperlukan dalam pemasaran produk agroindustri VCO diantaranya adalah: (i) kualitas produk, (ii) tempat pemasaran, (iii) harga produk yang dijual, dan (iv) kegiatan promosi. Selain itu, bimbingan dan penyuluhan kepada pelaku agroindustri VCO di Kabupaten Kulon Progo perlu dipertahankan dan ditingkatkan. Pendampingan perlu diberikan secara terstruktur dan berkelanjutan. Pelatihan yang diberikan perlu memperhatikan ketersediaan, kualitas, dan kontinuitas ketersediaan bahan baku, meningkatkan jiwa kewirausahaan dan ketrampilan SDM, teknologi produksi yang mampu diserap oleh pengusaha agroindustri VCO (industri kecil), serta peningkatan kualitas produk. Pemerintah perlu mendorong pola kemitraan baik antara agroindustri VCO dengan pemasok bahan baku. Tersedianya akses kredit bagi pelaku agroindustri VCO, dan terjalinnya pola kemitraan dengan industri rumah tangga penghasil VCO menjadi peluang dalam pengembangan agroindustri VCO. Selain itu, juga terdapat konsumen potensial baik dalam negeri maupun luar negeri. Peluang ini perlu dimanfaatkan untuk mengatasi kelemahan yang ada yang meliputi: (i) ukuran dan produktivitas gugus penjualan, (ii) kerjasama dengan jaringan distribusi, (iii) kemampuan menembus pasar potensial, (iv) diversifikasi produk berbahan baku kelapa, serta (v) kelancaran pembayaran penjualan produk.

Berdasar analisis SWOT melalui penilaian hasil analisis faktor internal (Tabel 1) dan faktor eksternal (Tabel 2) dapat digambarkan melalui diagram $X=$ $(-0,40)$ dan $\mathrm{Y}=(+0,55)$, maka pengembangan agroindustri $\mathrm{VCO}$ berada dalam posisi putar haluan (seperti pada Gambar 1). Posisi putar haluan yaitu mengatasi kelemahan yang ada untuk memanfaatkan peluang yang ada.

Berdasar hasil diagram analisis terlihat bahwa posisi pengembangan agroindustri VCO berada pada wilayah III yang berarti masih ada peluang untuk pengembangan walaupun masih terdapat kelemahan internal. Strategi untuk pengembangan agroindustri VCO yang harus dilakukan adalah dengan mengatasi masalah ukuran dan produktivitas gugus penjualan, kerjasama dengan jaringan distribusi, dan sistem pembayaran penjualan produk, serta kemampuan untuk menembus pasar potensial. Hal ini dilakukan untuk memanfaatkan peluang yang ada yaitu adanya konsumen protensial baik konsumen dalam maupun luar negeri yang didukung oleh sarana dan prasarana transportasi, dukungan pemerintah daerah dalam promosi produk, akses kredit, serta pola kemitraan yang sudah terbina.

Formulasi strategi pengembangan agroindustri VCO di Kabupaten Kulon Progo yang mengkombinasikan faktor-faktor internal (kekuatan dan kelemahan)) dengan faktor-faktor eksternal (peluang dan ancaman) disajikan dalam Tabel 3. 


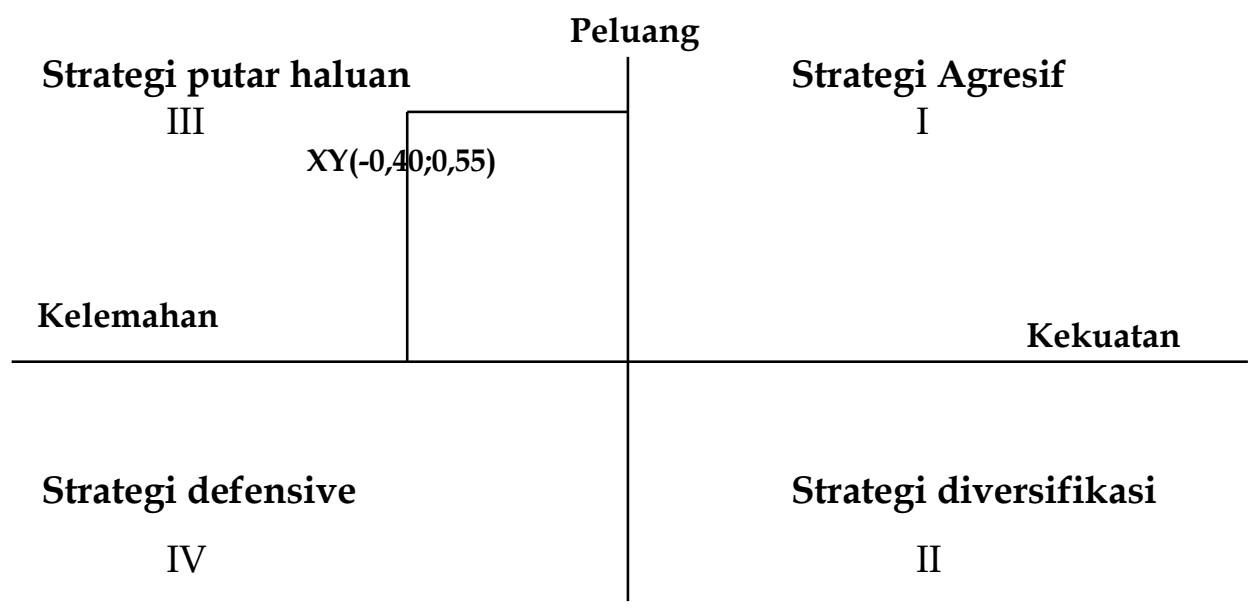

\author{
Ancaman \\ Gambar 1. \\ Diagram Analisis SWOT Pengembangan Agribisnis VCO \\ di Kabupaten Kulon Progo.
}

Tabel 3. Formulasi Strategi Pengembangan Agroindustri VCO, di Kabupaten Kulon Progo

\begin{tabular}{|c|c|c|}
\hline $\begin{array}{l}\text { Faktor } \\
\text { Eksternal }\end{array}$ & $\begin{array}{cl}\text { Kekuatan }(\mathbf{S}) \\
- & \text { Ketersediaan bahan baku } \\
- & \text { Kualitas bahan baku } \\
- & \text { Tingkat adopsi teknologi }\end{array}$ & $\begin{aligned} \text { Kelamahan }(\mathbf{W}) \\
\text { - } \\
\text { Ukuran dan produktivitas } \\
\text { gugus penjualan } \\
\text { - } \\
\text { Kerjasama dengan } \\
\text { jaringan distribusi } \\
-\quad \begin{array}{l}\text { Kemampuan menembus } \\
\text { pasar potensial }\end{array} \\
\end{aligned}$ \\
\hline $\begin{aligned} & \text { Peluang }(\mathbf{O}) \\
&-\quad \text { Transportasi } \\
&-\quad \text { Dukungan Pemda dalam } \\
& \text { promosi } \\
&- \text { Pola kemitraan } \\
&- \text { Konsumen potensial }\end{aligned}$ & $\begin{array}{l}\text { Strategi SO } \\
\text { Ketersediaan bahan baku, kualitas } \\
\text { bahan baku, tingkat adopsi } \\
\text { teknologi hendaknya menjadi } \\
\text { modal dasar untuk menembus } \\
\text { konsumen potensial yang } \\
\text { didukung oleh sarana dan } \\
\text { prasarana transportasi, pola } \\
\text { kemitraan dan dukungan Pemda } \\
\text { dalam promosi. }\end{array}$ & $\begin{array}{l}\text { Strategi WO } \\
\text { Adanya kelemahan (ukuran dan } \\
\text { produktivitas gugus penjualan, } \\
\text { kerjasama dengan jaringan } \\
\text { distribusi, kemampuan menembus } \\
\text { pasar potensial) dapat diatasi } \\
\text { dengan dukungan pemda dalam } \\
\text { promosi produk dan pola } \\
\text { kemitraan sehingga dapat } \\
\text { menembus konsumen potensial }\end{array}$ \\
\hline $\begin{array}{rll}\text { Ancaman }(\mathbf{T}) & \\
- & \text { Ketatnya persaingan } \\
- & \text { Kontinyuitas pesanan } \\
& \text { produk } & \\
- & \text { Persaingan } & \text { penggunaan } \\
& \text { bahan baku } & \end{array}$ & $\begin{array}{l}\text { Strategi ST } \\
\text { Kekuatan yang ada (ketersediaan } \\
\text { bahan baku, kualitas bahan baku, } \\
\text { tingkat adopsi teknologi) harus } \\
\text { ditingkatkan agar bisa } \\
\text { memenangkan persaingan produk } \\
\text { maupun bahan baku, serta } \\
\text { meningkatkan kontinyuitas } \\
\text { pesanan produk }\end{array}$ & $\begin{array}{l}\text { Strategi WT } \\
\text { Untuk menghadapi ketatnya } \\
\text { persaingan produk maupun bahan } \\
\text { baku, dan ketidakpastian pesanan } \\
\text { produk diperlukan peningkatan } \\
\text { ukuran dan produktivitas gugus } \\
\text { penjualan, kerjasama dengan } \\
\text { jaringan distribusi, serta } \\
\text { peningkatan kemampuan } \\
\text { menembus pasar potensial }\end{array}$ \\
\hline
\end{tabular}




\section{SIMPULAN}

1. Kekuatan dalam pengembangan agroindustri VCO meliputi ketersediaan dan kontinyuitas ketersediaan bahan baku, kualitas bahan baku yang digunakan, motivasi dalam berusaha, ketrampilan SDM, tingkat adopsi teknologi, serta standar kualitas produk yang diinginkan.

2. Kelemahan dalam pengembangan agroindustri VCO meliputi ukuran dan produktivitas gugus penjualan, kerjasama dengan jaringan distribusi, kemampuan menembus pasar potensial, diversifikasi produk, dan kelancaran pembayaran penjualan produk.

3. Peluang dalam pengembangan agroindustri VCO meliputi tersedianya sarana dan prasarana transportasi, dukungan pemda dalam promosi produk, kinerja penyuluh, akses kredit, pola kemitraan, konsumen potensial dalam dan luar negeri.

4. Ancaman dalam pengembangan agroindustri VCO meliputi munculnya teknologi baru yang diserap oleh industri besar, inflasi, semakin ketatnya persaingan produk, pesanan yang tidak menentu, persaingan penggunaan bahan baku.

5. Agroindustri VCO yang termasuk dalam kategori industri kecil berada dalam posisi putar haluan maka staratego untuk pengembangan agroindustri VCO (yang termasuk dalam ketegori industri kecil) adalah dengan mengatasi kelemahan untuk memanfaatkan peluang yang tersedia.

\section{DAFTAR PUSTAKA}

Anonim, 2005. Kulon Progo dalam Angka 2005. Biro Pusat Statistik Kabupaten Kulon Progo. 2007. Kulon Progo dalam Angka 2006/2007. Biro Pusat Statistik Kabupaten Kulon Progo. 2008. VCO: Minyak Perawan Ajaib. Nova Edisi Jumat 15 Februari 2008

Babbie, Earl, 1983. The Practice of social Research: Fouth Edition Wadsworth Co. New York.

Masyhuri, 2000. Pengembangan Agroindustri melalui Penelitian dan Pengembangan Produk yang Intensif dan Berkesinambungan. Agro Ekonomi. 7(1): 1 - 10.

Rangkuti, F., 2006. Analsis SWOT Teknis Membedah Kasus Bisnis. Gramedia, Jakarta.

Rindengan, B dan Novarianto, H (2004), Pembuatan dan Pemanfaatan Minyak Kelapa Murni. Swadaya, Jakarta.

Soetrisno, 1993. Agribisnis dalam Perspektif Undang-Undang Budidaya Tanaman dan Pembangunan Jangka Panjang Tahap II. Makalah disampaikan pada Seminar Strategi Pengembangan Agribisnis dalam PJPT II di Universitas Muhammadiyah Yogyakarta. 